\title{
AKTIVITAS PENGHAMBATAN XANTIN OKSIDASE PADA EKSTRAK DAUN SIRIH HITAM (Piper sp)
}

\author{
Muhammad Amir Masruhim, Wisnu Cahyo Prabowo, Dita Paramitha \\ Laboratorium RisetdanPengembangan FARMAKA TROPIS, \\ FakultasFarmasi,UniversitasMulawarman, Samarinda, Kalimantan Timur \\ Email: dta.chiko@gmail.com
}

\begin{abstract}
ABSTRAK
Hiperurisemia adalah keadaan dimana terjadi peningkatan kadar asam urat dalam darah. Xantinoksidase berperan dalam oksidasi hipoxantin dan xantin menjadi asam urat. Salah satu pengobatan hiperurisemia adalah menghambat xantinoksidase dalam proses pembentukan asam urat. Tujuan penelitian ini untuk mengetahui aktivitas penghambatan xantinoksidase pada ekstrak etanol daun sirih hitam (Piper sp). Pengujian aktivitas penghambatan xantinoksidase menggunakan metode spektrofotometri UV-Vis secara in vitro dengan konsentrasi $5 \mathrm{ppm}, 10 \mathrm{ppm}$, dan $20 \mathrm{ppm}$. Data yang didapat kemudian dianalisis menggunakan ANOVA satu arah. Hasil yang didapat adalah ekstrak etanol daun sirih hitam memiliki aktivitas yang berbeda signifikan, sehingga diperoleh nilai $\mathrm{IC}_{50}$ sebesar 65,96 ppm.
\end{abstract}

Kata kunci: Piper $s p$, XantinOksidase, Hiperurisemia

\begin{abstract}
Hyperuricemia is a condition in which increased levels of uric acid in the blood. Xanthine oxidase role in the oxidation of hypoxanthine and xanthine to uric acid. One treatment of hyperuricemia is inhibiting xanthine oxidase in the process of formation of uric acid. The purpose of this study to determine the inhibitory activity of xanthine oxidase in the ethanol extract of black betel leaf (Piper $s p$ ). Xanthine oxidase inhibitory activity test using UVVis spectrophotometry in vitro with a concentration of $5 \mathrm{ppm}, 10 \mathrm{ppm}$ and $20 \mathrm{ppm}$. The data obtained were analyzed using one-way ANOVA. The result is the ethanol extract of black betel leaf has a different activity significantly and IC50 values obtained is 65.96 ppm.
\end{abstract}

Key words: Piper $s p$, Xanthine Oxidase, Hyperuricemia

\section{PENDAHULUAN}

Hiperurisemia adalah peningkatan kadar asam urat dalam darah lebih dari $7 \mathrm{mg} / \mathrm{dL}$ pada pria dan $6 \mathrm{mg} / \mathrm{dL}$ pada wanita. Asam urat merupakan hasil akhir dari katabolisme purin. Dalam proses katabolisme purin tersebut xantinoksidase mengkatalisis xantin dan hipoxantin menjadi asam urat [1].

Adanya efek samping obat sintetik menyebabkan penderita lebih memilih menggunakan pengobatan herbal. Daun sirih hitam mengandung metabolit sekunder diantaranya alkaloid, karetenoid, senyawa fenolik, flavonoid, saponin, tannin dan steroid yang diduga memiliki aktivitas penghambatan terhadap xantinoksidase [2]. 
Berdasarakan adanya kandungan metabolit sekunder tersebut maka dilakukan pengujian aktivitas penghambatan xantinoksidase ekstrak daun sirih hitam (Piper Sp).

\section{METODE PENELITIAN \\ Bahan}

Bahan yang diteliti adalah simplisia daun sirih hitam. Pelarut yang digunakan untuk ekstraksi adalah etanol. Enzim yang digunakan adalah enzim xantinoksidase (Sigma Aldrich X1875-5UN). Substrat yang digunakan adalah xantin. Buffer fosfat $\mathrm{pH} 7,5$ digunakan sebagai media pembawaenzim.

\section{Peralatan}

Peralatan yang digunakan dalam penelitian ini antara lain wadah maserasi, rotary evaporator, waterbath, timbangan analitik, gelas kimia, labu ukur, tabung reaksi, mikro pipet, dan alat penunjang lainnya.

\section{Prosedur}

\section{PengumpulanSampel}

Daun sirih hitam diperoleh di daerah Jalan Antasari, Kota Samarinda, Kalimantan Timur. Daun sirih hitam segar dikumpulkan kemudian disortasi. Setelah itu, dicuci dan dikeringkan dengan cara diangin-anginkan didalam ruangan yang terlindung dari sinar matahari. Selanjutnya daun sirih hitam kering disortasi kembali dan dipotong kecil-kecil menjadi serbuk simplisia.

\section{Ekstraksi}

Serbuk simplisia dimasukkan kedalam wadah maserasi dan dimaserasi menggunakan pelarut etanol. Proses maserasi berlangsung selama kurang lebih 3 hari. Maserat (hasil maserasi) disaring menggunakan kertas saring dan ditampung kedalam wadah. Kemudian dipekatkan menggunakan rotary evaporator dan dilanjutkan dengan penguapan di atas waterbath hingga diperoleh ekstrak kental etanol.

\section{PengujianAktivitasPenghambatanXantinOksidase}

Pengujian aktivitas penghambatan xantinoksidase dilakukan dengan mencampurkan $1 \mathrm{ml}$ larutan sampel daun sirih hitam $(5,10,20 \mathrm{ppm})$, ditambah 2,9 $\mathrm{ml}$ buffer fosfat $(\mathrm{pH}$ 7,5), dan ditambahkan $2 \mathrm{ml}$ substrat xantin $(0,5 \mathrm{mM})$ kemudian diinkubasi pada suhu ruang selama 10 menit. Substrat xantin disiapkan dengan melarutkan 7,605 mg xantindengan sedikit $\mathrm{NaOH}$ hingga larut, kemudian ditambahkan aquadest sampai $100 \mathrm{ml}$. Setelah preinkubasi, ditambahkan $0,1 \mathrm{ml}(0,1 \mathrm{unit} / \mathrm{ml}$ dalam buffer fosfat $\mathrm{pH} 7,5)$ enzim xantinoksidase (Sigma Aldrich X1875). Campuran larutan kemudian diinkubasi pada suhu ruang selama 30 menit dan ditambah $1 \mathrm{ml}$ HCL $1 \mathrm{~N}$ untuk menghentikan reaksi. Absorbansi diukur pada panjang gelombang $262 \mathrm{~nm}$ menggunakan spektrofotometer UVVis. Aktivitas xantinoksidase dinyatakan dalam persentase penghambatan xantinoksidase, yang dihitung dengan menggunakan rumus:

$$
\text { Persen penghambatan }=\frac{\mathrm{B}-\mathrm{A}}{\mathrm{B}} \times 100 \%
$$

Dimana B adalah aktivitas enzim tanpa ekstrak ( $\Delta$ abs. Dengan enzim - $\Delta$ abs. Tanpa enzim), dan $A$ adalah aktivitas enzim dengan ekstrak ( $\Delta$ abs. Dengan enzim $-\Delta$ abs tanpa enzim). 


\section{HASIL DAN PEMBAHASAN}

Pengujian aktivitas penghambatan xantinoksidase ekstrak etanol daun sirih hitam dilakukan dengan menggunakan 3 konsentrasi yaitu 5 ppm, 10 ppm, dan 20 ppm. Hasil pengujian dari aktivitas penghambatan xantinoksidase dapat dilihat pada Tabel 1 .

\begin{tabular}{|c|c|c|c|c|c|}
\hline \multirow{2}{*}{$\begin{array}{c}\text { Konsentrasi } \\
\text { (ppm) }\end{array}$} & \multicolumn{3}{|c|}{ Absorbansi } & \multirow{2}{*}{$\%$ inhibisi } & \multirow{2}{*}{ IC 50} \\
\hline & kontrolsampel & sampel & ks-s & & \\
\hline 5 & 1,3563 & 0,7093 & 0,6470 & $10,5983 \%$ & \multirow{4}{*}{65,9648} \\
\hline 10 & 1,3633 & 0,7283 & 0,6347 & $12,2979 \%$ & \\
\hline 20 & 1,3443 & 0,7663 & 0,578 & $20,1326 \%$ & \\
\hline blanko & 1,5450 & 0,8213 & 0,7237 & & \\
\hline
\end{tabular}

Xantinoksidase adalah enzim yang memainkan peran penting dalam hiperurisemia, mengkatalisis oksidasi hipoksantin menjadi xantine dan kemudian menjadi asam urat. Para ilmuwan menjelajahi potensi penghambatan xantinoksidase dari berbagai macam tanaman herbal tradisional (Owen et al, 1999; Kong et al, 2000.). Hastuty (2011) melaporkan bahwa ekstrak etanol daun sirih hitam mengandung saponin, tannin, fenolik, flavonoid, serta alkaloid. Aktivitas penghambatan xantinoksidase oleh polifenol (Costantino et al., 1992), tannin (Hatano et al., 1990), serta flavonoid (Cakir et al., 2003) telah dilaporkan.

Tabel 1 di atas menunjukkan bahwa ekstrak etanol daun sirih hitam pada konsentrasi 5 ppm, 10 ppm dan 20 ppm memiliki aktivitas dalam menghambat xantinoksidase. Pengujian pada beragam konsentrasi ini ditujukan untuk melihat pengaruh penambahan konsentrasi ekstrak pada peningkatan daya inhibisi. Selain itu juga dilakukan pengamatan aktivitas enzim tanpa penambahan ekstrak (blanko) untuk melihat pengaruh inhibisi ekstrak tersebut pada aktivitas enzim. Setelah dilakukan analisis statistik menggunakan one way ANOVA, dengan taraf signifikansi $0,05(\alpha=0,05)$ menunjukkan bahwa terdapat perbedaan yang signifikan terhadap nilai absorbansi tiap konsentrasi. Hal ini berarti bahwa tiap konsentrasi memiliki aktivitas penghambatan xantinoksdase yang berbeda. Penghambatan xantinoksidase mengakibatkan penurunan produksi asam urat, yang diukur dengan spektrofotometer UV-Vis. Penghambatan 50\% diperoleh pada konsentrasi 65,96 ppm.

\section{KESIMPULAN}

Ekstrak daun sirih hitam (Piper sp.) memiliki aktivitas penghambatan xantinoksidase dengan nilai $\mathrm{IC}_{50}$ sebesar $65,96 \mathrm{ppm}$.

\section{DAFTAR PUSTAKA}

1. Price, S. A., dan Wilson, L. M. 2005. PatofisiologiKonsepKlinis Proses-Proses PenyakitEdisi 6 Volume 2. EGC. Jakarta.

2. Hastuty, R.K. 2011. IdentifikasiMetabolitSekunderdanUjiToksisitasdenganMetodeBSLT. SkripsiFakultasFarmasiUniversitasMulawarman.Samarinda.

3. Owen, P.L. \& Johns, T. (1999). Xanthine oxidase inhibitory activityof northeastern North American plant remedies used for gout.Journal of Ethnopharmacology, 64, 149-160.

4. Kong, L.D., Cai, Y., Huang, W.W., Cheng, C.H. \& Tan, R.X.(2000). Inhibition of xanthine oxidase by some Chinese medicinalplants used to treat gout. Journal of Ethnopharmacology, 73, 199-207. 
5. Costantino, L., Albasini, A., Rastelli, G. \&Benvenuti, S. (1992).Activity of polyphenolic crude extracts as scavengers of superoxideradicals and inhibitors of xanthine oxidase. PlantaMedica, 58,342-344.

6. Cakir, A., Mavi, A., Yildirim, A., Duru, M.E., Harmandar, M. \&Kazaz, C. (2003). Isolation and characterization of antioxidantphenolic compounds from the aerial parts of HypericumhyssopifoliumL. by activity-guided fractionation. Journal of Ethnopharmacology,87, 73-83.

7. Hatano, T., Yasuhara, T., Yoshihara, R., Agata, I., Noro, T. \& Okuda,T. (1990). Effects of interaction of tannins with co-existing substances.Inhibitory effects of tannins and related polyphenols on xanthine oxidase. Chemical and Pharmaceutical Bulletin, 38, 1224-1229. 